\title{
Evaluation of some Garden Pea Cultivars for Growth and Yield Char- acteristics under Assiut Conditions
}

\author{
Haridy, A.G.H. ${ }^{1}$; H.S. Abbas ${ }^{1}$; K.A. Amein ${ }^{2}$ and Fatma E. Mahmoud ${ }^{1}$
}

${ }^{1}$ Department of Vegetable Science, Fac. of Agriculture, Assiut Univ., Assiut, Egypt

${ }^{2}$ Department of Genetics, Fac. of Agriculture, Assiut Univ., Assiut, Egypt

Received on: 1/9/2019

Accepted for publication on: 3/9/2019

\section{Abstract}

An experiment was conducted in 2016/2017 and 2017/2018 seasons to study the performance of different cultivars of garden pea under Assiut condition. Five cultivars were evaluated on black soil in replicated randomized block design and results were found significant for all characters among these cultivars. All cultivars exhibited considerable variation in their performance for most of the parameters. Better growth and yield parameters in terms of days to flowering, number of branches/plant, green pod length, green pod width, number of green pod/plant, number of seeds per pod, total dry seed yield per feddan were noticed in all cultivars. Maximum number of branches per plant was observed in Alaska (6.5) and minimum was in Master B (4.5). In case of number of pods per plant was maximum in Dwarf Gray Sugar (64.8) followed by Victory Freezer (60.0) and minimum in Lincoln (52.5). Among all these cultivars, highest total dry seed yield was recorded in Master B cultivar (1430.30 and $1440.50 \mathrm{~kg} /$ Fadden respectively). As general Alaska and Dwarf Gray Sugar may be selected as promising cultivars under Assiut conditions.

\section{Keywords: Garden pea, Cultivars, Yield.}

\section{Introduction}

Pea (Pisum sativum L.) is one of the important favorable vegetable crops grown in Egypt. Green peas have a nutritionally favorable composition in respect to macronutrients: low fat, high fiber and protein content (National Food Administration 1, 2002), and starch with a low glycemic index (Foster-Powell et al. 1995). Among micronutrients, peas have high ascorbic acid, carotene, thiamine and riboflavin content and, comparing with other vegetables, they are rich in iron (National Food Administration 1, 1995 and Nilsson et al., 2004).

\section{Material and Methods}

The present investigation was carried out on a clay soil at the experimental farm, Faculty of Agricul- ture, Assiut University, Assiut, in 2016/2017 and 2017/2018 seasons. Seeds of five Garden pea (Pisum sativum L.) Cultivars namely; Lincoln, Alaska, Victory Freezer, Master B and Dwarf Gray Sugar, were planted in pre- irrigated soil which had about $50 \%$ of its available moisture. Seeds sown con October 16 and 18 for the $1^{\text {st }}$ and $2^{\text {nd }}$ year, respectively.

A randomized complete block design with three replicates was used, each represented by 5 plots of the lines. Each experimental plot consisted of five rows, $3.5 \mathrm{~m}$ long and 60 $\mathrm{cm}$ wide. All plots were planted by hand with one seed per hill along the both southern and northern sides of ridges. Hills were spaced $30 \mathrm{~cm}$ apart. The normal cultural practices of cultivation, irrigation, fertilization, 
weed and pest control of garden pea were followed as recommended for the region.

\section{Experimental procedures}

Data were collected for the following characters

1- Days to flowering, recorded as number of days from planting to flowering i.e., when $50 \%$ of the plants were in bloom.

2- Number of branches per plant, counted also at harvest.

3- Green pod length, in $\mathrm{cm}$, at the time of green harvest.

4- Green pod width, in $\mathrm{cm}$, at the time of green harvest.

5- Number of pods per plant as total harvested pods.

6- Number of seeds per pod as average of seeds number per 20 pods.

7- Total dry seed yield in $\mathrm{kg} /$ feddan.

\section{Statistical analysis:}

Analysis of variance of RCBD experiments as described by (Gomez and Gomez 1984) was performed. All data were subjected to statistical analysis using $\mathrm{F}$ test and means were compared using Duncan's test.

\section{Results and Discussion}

The results of yield and yield components of certain garden pea genotypes, which were studied in this experiment are presented in Tables 1 and 2.

\section{1- Days to flowering}

Number of days to flowering was markedly affected by cultivars. Garden pea genotypes showed significant differences in days to flowering in both seasons. In the first season, time to flowering of the used cultivars ranged from 58.5 and 57.5 days for Master B to 74.5 and 75.5 days for Victory Freezer. In the first and second season respectively. Cultivar Master B was the earliest line in both seasons, while cultivar Victory Freezer was the latest in flowering also in both seasons. The other Garden Pea cultivars were in between.

\section{2- Number of branches per plant}

The variations in the values shown by number of branches per plant are significant in both seasons. In the first season, it ranged from 4.7 branches to 6.5 branches. Alaska recorded the highest value (6.5 branches) followed by Victory Freezer (5.8 branches), which was not significant different from Dwarf Gray Sugar (5.6 branches) and Lincoln (5.5 branchess). In the second season, the values of number of branches per plant ranged from 4.5 branches to 6.0 branches. Alaska recorded the highest value (6.0 branches), while cultivar Master B recorded the lowest value (4.5 branchess). The other garden pea cultivars were in between. More time to flowering in some genotypes with more number of branches is an indication of more vegetative growth due to climatic condition. It was observed that some genotypes had determinate type growth and their plant bloomed and exhausted simultaneously, hence these had less branches per plant as have been observed by Hussain and Badshah (2002). Variation could be due to genetic variability of different germplasm. Similar results were elucidated by Wadan et al. (1993).

\section{3- Green pod length}

Green pod length was significantly affected by cultivars in the first season and ranged from $12.3 \mathrm{~cm}$ to $15.8 \mathrm{~cm}$, the pod length of cultivar Master B $(15.8 \mathrm{~cm})$ was significantly longer than all other cultivars and fol- 
lowed by cultivars Alaska $(14.4 \mathrm{~cm})$, Victory Freezer $(13.6 \mathrm{~cm})$ and Assiut $48(8.89 \mathrm{~cm})$, while lincoln recorded the lowest value for pod length $(12.3$ $\mathrm{cm})$. In the second season, the green pod length ranged from $11.5 \mathrm{~cm}$ to $15.00 \mathrm{~cm}$. Master $\mathrm{B}$ recorded the highest value of pod length (15.0 $\mathrm{cm})$. Alaska $(14.0 \mathrm{~cm})$ and Victory Freezer $(13.5 \mathrm{~cm})$ were not significantly different in pod length followed by Dwarf Gray Sugar (12.5 $\mathrm{cm})$ while cultivar Lincoln recorded the lowest value for pod length (11.5 $\mathrm{cm})$.

\section{4- Green pod width}

Results revealed that green pod width was significantly different with Garden Pea cultivars. In the first season, the values ranged from $0.74 \mathrm{~cm}$ to $0.89 \mathrm{~cm}$. Master B recorded the highest value $(0.89 \mathrm{~cm})$ followed by Victory Freezer $(0.87 \mathrm{~cm})$, Dwarf Gray Sugar $(0.81 \mathrm{~cm})$, Alaska $(0.79$ $\mathrm{cm})$ and Lincoln $(0.74 \mathrm{~cm})$. In the second season, the green pod width at five cultivars ranged from $0.70 \mathrm{~cm}$ to $0.90 \mathrm{~cm}$. Master B recorded the highest value of pod width $(0.90 \mathrm{~cm})$, while cultivar Lincoln recorded the lowest value $(0.70)$, the other cultivars were in between.

\section{5- Number of pods per plant}

Data revealed clearly that there are significant differences between garden pea cultivars in number of pods per plant in all growing seasons under study. Garden Pea cultivars ranged from 52.50 pods to 64.80 pods and from 49.50 pods to 65.0 pods in the two seasons, respectively. In the first season, cultivar Dwarf Gray Sugar produced the highest number of pods per plant (64.80 pods) followed by Victory Freezer (60.0 pods), while cultivar Lincoln produced the lowest number of pods per plant (52.5 pods). In the second season, cultivar Dwarf Gray Sugar (65.0 pods) ranked first for number of pods per plant and Lincoln (49.5 pods) ranked last. The other Pea cultivars were in between. Some researchers observed number of pods per plant as the most useful yield component. These findings agree with Javaid et al. (2002) and Khan et al. (2013).

\section{6- Number of seeds per pod}

The behavior of this character was differed significantly between Garden Pea cultivars and ranged from 9.8 seeds to 10.8 seeds and from 9.5 seeds to 10.55 seeds in the two seasons, respectively. In the first season, Victory Freezer gave the highest value (10.8 seeds) but not significantly different from Master B (10.78 seeds) followed by Lincoln (10.5 seeds) but not significantly different from Alaska (9.85 seeds). In the second season, Master B gave the highest value (10.55 seeds) of seeds per pod. Dwarf Gray Sugar (9.5 seeds) gave the lowest value, which was not significantly different from Alaska ( 9.75 seeds). The possible reason of less number of seeds per pod may be that environment was not suitable at the time of pollination and fertilization. These findings are in agreement with Ali et al. (2002a) and Quasim et al. (2001).

\section{7- Total dry seed yield (kg/feddan)}

The five cultivars of Garden Pea showed significant differences in total seed yield in both seasons and ranged from $955.20 \mathrm{~kg} /$ feddan to $1430.30 \mathrm{~kg} /$ feddan and from 940.50 $\mathrm{kg} /$ feddan to $1440.50 \mathrm{~kg} /$ feddan in the two seasons, respectively. In the 
first season, the highest yield was obtained from cultivar Master B (1430.30 kg/feddan) followed by Dwarf Gray Sugar (1315.35 $\mathrm{kg} /$ feddan), Alaska (1280.35/feddan), while Lincoln gave the lowest yield (955.20 kg/feddan). In the second season, the highest yield was obtained from Master B (1440.50 $\mathrm{kg} /$ feddan). Cultivar Lincoln gave the lowest yield (940.50 kg/feddan). More yields in different genotypes may be due to optimum plant survival, long and more number of seeds per pod, which ultimately contributed significantly towards final yield. The performance of a cultivar mainly depends on interaction of genetic makeup and environment. These findings are in agreement with Arshad et al. (1998). Similar results have also been reported by Natarajan and Arumugam (1983) who observed that positive association of grain yield with plant height, pods per plant.

\section{References:}

Ali, I.; Rub, A. and Ali, S.A. 2002a. Performance of pea germplasm for seed yield and yield components under Peshawar conditions. Sarhad. J. Agric. 18(1): 39-43.

Arshad, M.; Hussain, S.A.; Ali, S. A. N.; Muhammad, N. and Ziaullah. 1998. Screening of pea (Pisum sativum L.) cultivars in Kohat valley. Sarhad J. Agric. 14(6): 559-562.

Hussain, S.A. and N. Badshah. 2002. Study on the adaptive behaviour of exotic pea (Pisum sativum L.) varities under local condition of Peshawar. Asian J. Plant Sci. 1(5): 567-569.

Foster-Powell, K. and J.B. Miller 1995. International tables of glycemic index, American Journal of Clinical Nutrition 62: 871S-893S.

Gomez, K.A. and A.A. Gomez 1984. Statistical Procedures for Agricul- tural Research (2 ${ }^{\text {nd }}$ Ed.). John Wiley and Sons. New York.

Fu Z, Jin X, Ding D, Li Y, Fu Z, Tang J. 2011. Proteomic analysis of heterosis during maize seed germination. Proteomics. 11:1462-1472.

Javaid, A.; Ghafoor and Anwar, R. 2002. Evaluation of local and exotic pea (Pisum sativum) germplasm for vegetative and dry grain traits. Pak. J. Bot. 34(4): 419-427.

Khan, T.N.; Ramzan, A.; Jillani, G.; and Mehmood, T. 2013. Morphological performance of peas (Pisum sativum L.) genotypes under rainfed conditions of potowar region. J. Agric. Res., 51(1): 51-60.

Natarajan, S. and Arumugam, R. 1983. Evaluation of pea (Pisum sativum L.) cultivars of Kodiakanal hills. South Indian Horticulture. 31(1): 7-10.

National Food Administration, Food composition database 2002, ver. 02.2, code 1155, Uppsala, Sweden.

Nei, M. and W. H. Li 1979. Mathematical model for studying genetic variation in terms of restriction endonucleases. Proc. Natl. Acad. Sci. USA., 76: 5269-5273.

Nilsson, J., R. Stegmark and B. Akesson 2004. Total antioxidant capacity in different pea (Pisum sativum) varieties after blanching and freezing, Food Chemistry 86(), 501507.

Qasim, M.; Zubair, M. and Wadan, D. 2001. Evaluation of exotic cultivars of pea in Swat valley. Sarhad J. Agric. 17(4): 545-548.

Santalla, M, Amurrio, J. M. and De Ron, A.M. 2001. Food and feed potential breeding of green, dry and vegetable pea germplasm. Can. J. Plant Sci. 81: 601-610.

Wadan, D.; Khan, M. and Majeed, A. 1993. Performance of pea cultivars in various agro climatic conditions of Swat. Sarhad J. Agric. 9 (2): 139-143. 
Website: www.aun.edu.eg/faculty_agriculture/journals_issues_form.php E-mail:ajas@aun.edu.eg

Table 1. Yield and yield components of certain garden pea cultivars grown in 2016-2017 and 2017-2018 seasons, respectively.

\begin{tabular}{|l|c|c|c|c|c|c|c|c|}
\hline \multirow{2}{*}{ Cultivars } & \multicolumn{2}{|c|}{ Days to flowering } & \multicolumn{2}{|c|}{$\begin{array}{c}\text { Number of } \\
\text { branches/ plant }\end{array}$} & \multicolumn{2}{c|}{ Green pod length } & \multicolumn{2}{c|}{$\begin{array}{c}\text { Green pod width } \\
\text { (cm) }\end{array}$} \\
\cline { 2 - 9 } & $2016 / 2017$ & $2017 / 2018$ & $2016 / 2017$ & $2017 / 2018$ & $2016 / 2017$ & $2017 / 2018$ & $2016 / 2017$ & $2017 / 2018$ \\
\hline Lincoln & $71.5 \mathrm{a}$ & $70.5 \mathrm{a}$ & $5.5 \mathrm{~b}$ & $5.5 \mathrm{~b}$ & $12.3 \mathrm{c}$ & $11.5 \mathrm{c}$ & $0.74 \mathrm{~b}$ & $0.70 \mathrm{~b}$ \\
\hline Alaska & $67.5 \mathrm{~b}$ & $65.5 \mathrm{~b}$ & $6.5 \mathrm{a}$ & $6.0 \mathrm{a}$ & $14.4 \mathrm{~b}$ & $14.0 \mathrm{~b}$ & $0.79 \mathrm{~b}$ & $0.75 \mathrm{~b}$ \\
\hline Victory Freezer & $74.5 \mathrm{a}$ & $75.5 \mathrm{a}$ & $5.8 \mathrm{~b}$ & $5.5 \mathrm{~b}$ & $13.6 \mathrm{~b}$ & $13.5 \mathrm{~b}$ & $0.87 \mathrm{a}$ & $0.90 \mathrm{a}$ \\
\hline Master B & $58.5 \mathrm{c}$ & $57.5 \mathrm{c}$ & $4.7 \mathrm{c}$ & $4.5 \mathrm{c}$ & $15.8 \mathrm{a}$ & $15.0 \mathrm{a}$ & $0.89 \mathrm{a}$ & $0.90 \mathrm{a}$ \\
\hline Dwarf Gray Sugar & $65.5 \mathrm{~b}$ & $64.5 \mathrm{~b}$ & $5.6 \mathrm{~b}$ & $5.5 \mathrm{~b}$ & $12.4 \mathrm{c}$ & $12.5 \mathrm{c}$ & $0.81 \mathrm{a}$ & $0.80 \mathrm{a}$ \\
\hline
\end{tabular}

Duncan's multiple ranges test. Values with the same letter are not significantly different.

Table 2. Yield and yield components of certain garden pea cultivars grown in 2016-2017 and 2017-2018 seasons, respectively.

\begin{tabular}{|l|c|c|c|c|c|c|}
\hline Cultivars & \multicolumn{2}{|c|}{ Number of pods/ plant } & \multicolumn{2}{c|}{ Number of seeds /pod } & \multicolumn{2}{c|}{$\begin{array}{c}\text { Total dry seed yield } \\
\text { (kg/feddan) }\end{array}$} \\
\hline & $\mathbf{2 0 1 6 / 2 0 1 7}$ & $\mathbf{2 0 1 7 / 2 0 1 8}$ & $\mathbf{2 0 1 6 / 2 0 1 7}$ & $\mathbf{2 0 1 7 / 2 0 1 8}$ & $\mathbf{2 0 1 6 / 2 0 1 7}$ & $\mathbf{2 0 1 7 / 2 0 1 8}$ \\
\hline Lincoln & $52.5 \mathrm{~b}$ & $49.5 \mathrm{~b}$ & $10.5 \mathrm{a}$ & $10.5 \mathrm{a}$ & $955.20 \mathrm{~d}$ & $940.50 \mathrm{~d}$ \\
\hline Alaska & $56.5 \mathrm{~b}$ & $55.0 \mathrm{~b}$ & $9.85 \mathrm{ab}$ & $9.75 \mathrm{ab}$ & $1280.35 \mathrm{~b}$ & $1277.00 \mathrm{~b}$ \\
\hline Victory Freezer & $60.0 \mathrm{a}$ & $58.0 \mathrm{a}$ & $10.8 \mathrm{a}$ & $10.0 \mathrm{a}$ & $1170.30 \mathrm{c}$ & $1185.00 \mathrm{c}$ \\
\hline Master B & $56.8 \mathrm{~b}$ & $55.5 \mathrm{~b}$ & $10.78 \mathrm{a}$ & $10.55 \mathrm{a}$ & $1430.30 \mathrm{a}$ & $1440.50 \mathrm{a}$ \\
\hline Dwarf Gray Sugar & $64.8 \mathrm{a}$ & $65.0 \mathrm{~b}$ & $9.8 \mathrm{ab}$ & $9.5 \mathrm{ab}$ & $1315.35 \mathrm{~b}$ & $1332.00 \mathrm{~b}$ \\
\hline
\end{tabular}

Duncan's multiple ranges test. Values with the same letter are not significantly different. 
تقييم بعض أصناف البسلة لصفات النمو والمحصول تحت ظروف أسيوط

أثرف جلال هريدي'، حسن سيد عباس'، كرم عبد النعيم أمين 'وفاطمة الأمير محمود'

$$
\begin{aligned}
& \text { ' قسم الخضر - كلية الزر اعة - جامعة أسيوط }
\end{aligned}
$$

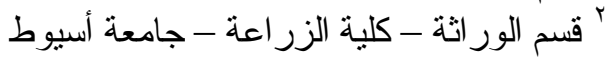

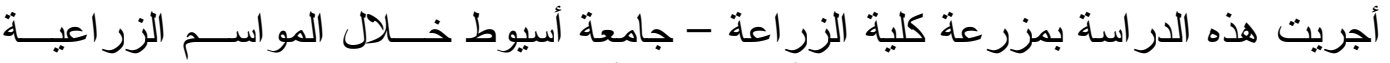

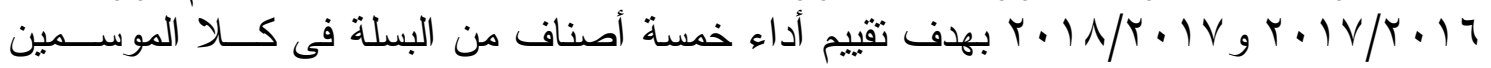

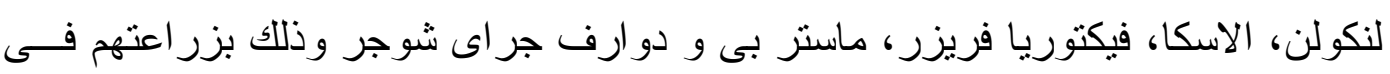
وهي: ثلاث مكرر ات فى قطاعات كاملة العشو ائية وتم در استة الصفات دات الآتية:

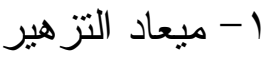

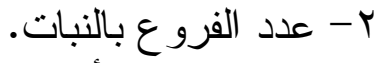
ب- ب- طول القرن الأخضر (سم) ع - قطر القرن الأخضر (سم).

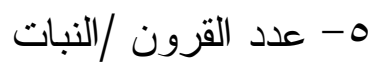

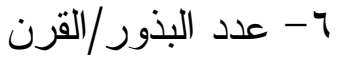

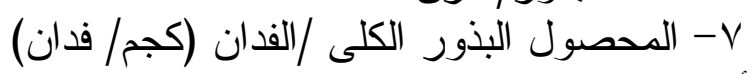

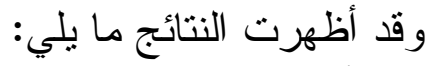

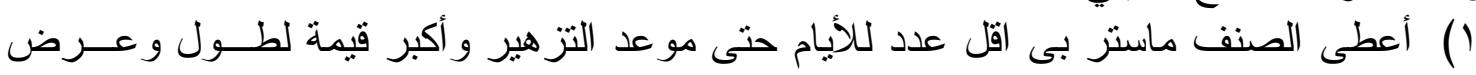
القرن الاخضر في كلا الموسمين.

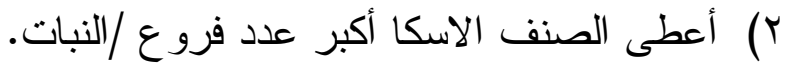

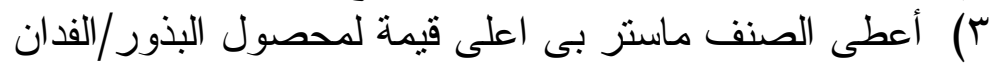

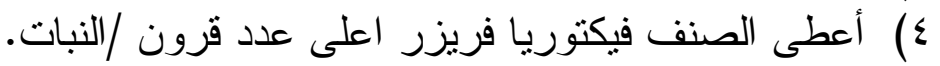

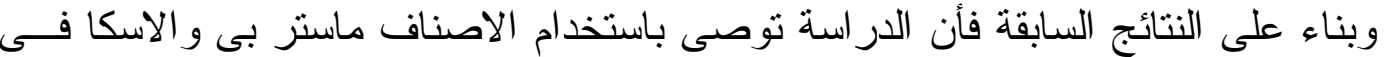
الإنتاج العالى و المبكر للبسلة تحت ظروف أسيوط. 